\title{
Trodimenzionalne kulture ljudskih stanica uzgojene radi testiranja citotoksičnosti stomatoloških materijala
}

\section{Three-Dimensional Human Cell Cultures for Cytotoxicity Testing of Dental Filling Materials}

\author{
${ }^{1}$ Zavod za opću stomatologiju i parodontologiju, Sveučilište Regensburg, Njemačka \\ Department of Operative Dentistry and Periodontology, University of Regensburg, Germany \\ 2 Stomatološki fakultet (ZKM Bern), Sveučilište u Bernu, Švicarska \\ School of Dental Medicine (ZMK Bern), University of Bern, Switzerland \\ 3 Privatna praksa, Lechstr. 11b, 93026 Rosenheim, Njemačka \\ Private Practice, Lechstr. 11b, 93026 Rosenheim, Germany
}

\section{Sažetak}

Cilj: Za uzgoj trodimenzionalnih kultura stanica radi testiranja citotoksičnosti stomatoloških materijala u testu dentinske barijere (DBT) dosad su se rabile "besmrtne" stanice goveđe pulpe. U ovom istraživanju ocijenili smo uporabu stanica dobivenih iz ljudske pulpe koje bi mogle preciznije simulirati kliničku situaciju. Također, testirali smo smolasti kompozitni materijal. Materijali i metode: SV40-transfektirane stanice ljudske pulpe (tHPC) uzgojene su u hidrogelu (fibrin, peptid, kolagen) te su određena mehanička svojstva i vitalnost stanica (MTT I WST-1). Na uzorcima stanica uzgojenih u kolagenu proveden je test proliferacije stanica nakon četiri tjedna (WST-1). Nakon 14 dana na uzgojenim trodimenzionalnim kulturama stanica u kolagenu proveden je DBT test s $200 \mu \mathrm{m}$ debelim dentinskim diskovima. Nakon inkubacije od 24 sata pod perfuzijom $(0.3 \mathrm{ml} / \mathrm{h})$ upotrijebljeni su materijali prema uputama proizvođača (1) President (Coltene): negativna (netoksična) kontrola, (2) CaGPG14 (ISO 7405): pozitivna (toksična) kontrola, (3) Tetric EvoCeram (Ivoclar Viadent) s Clearfil SEBond (Kuraray, referentni materijal), (4) N`Durance (Sepodont, testni materijal), (5) N`Durance s Clearfil SEBond. Ocijenjena je vitalnost stanica nakon inkubacije od 24 sata (WST-1). Izračunat je postotak relativne vitalnosti (negativna kontrola $=100 \%$ ) i provedena je statistička analiza (Kruskal-Wallisov test, $\mathrm{p} \leq 0.05$ ). Rezultati: Hidrogelovi od fibrina i peptida pokazali su nedostatna mehanička svojstva za DBT. Kolagenski gel pokazao se pogodnim za trodimenzionalnu kulturu stanica tHCP do 21 dan. Nakon toga uzorci su preneseni na DBT analizu te su rezultati bili slični onima iz prijašnjih istraživanja s goveđim stanicama. DBT test, primjenjujući tHPC, u kolagenu nije pokazivao statistički značajne razlike između testiranih materijala $s$ adhezivom i bez njega i referentnih smolastih kompozita. Zaključak: tHCP u kolagenu može nadomjestiti goveđe stanice u DBT testu. Testirani materijal ne uzrokuje oštećenje pulpe ako je prekrivena intaktnim slojem dentina.
Zaprimljen: 30. svibnja 2014

Prihvaćen: 16. lipnja 2014.

Adresa za dopisivanje Professor Gottfried Schmalz University of Regensburg

Department of Operative Dentistry and Periodontology

93042 Regensburg, Germany

Tel. 0941-9444980

Fax. 0941-9444981

Gottfried.Schmalz@klinik.uniregensburg.de

\section{Ključne riječi}

Stanice, dentalni materijali

\section{Uvod}

Stomatološki su materijali u dugotrajnom kontaktu s vitalnim tkivom. Upravo zbog toga ti materijali moraju proći postupak certifikacije, koju je propisalo nacionalno i internacionalno zakonodavno tijelo, prije nego što ih se smije pustiti u prodaju (1). Dio certificiranja podrazumijeva i procjenu kliničkog rizika biokompatibilnosti materijala. Osnovne informacije u ovom kontekstu uključuju informacije dobivene od testova citotoksičnosti pa se oni smatraju relevantnim internacionalnim standardima i često se rabe za vrijeme procjene kliničkog rizika (1-3).

Testovi citotoksičnosti klasificirani su na testove u kojima je stomatološki materijal u izravnom kontaktu sa stanicama (1) I testovi u kojima postoji barijera između materijala i stanica $(2,3)$. Za testiranje citotoksičnosti stomatoloških ma-

\section{Introduction}

Dental filling materials come into long-term contact with living tissues. Therefore - according to national and international medical device legislation - they must pass a certification process before they are allowed to be marketed (1). Part of this certification is a clinical risk assessment including a biocompatibility evaluation. Basic biological information in this context is - amongst others - derived from cytotoxicity tests and, therefore, cytotoxicity test methods are included into the relevant international standards which are commonly used in the course of clinical risk assessment (1-3).

Such cytotoxicity tests can be classified in (1) those with direct contact between the target cells and the material/eluate from a material and (2) those with a barrier between them $(2,3)$. For cytotoxicity testing of dental filling mate- 
terijala koriste se diskovi goveđeg dentina različite debljine koji dobro simuliraju in-vivo situaciju u ustima (4-8). Ova metoda testiranja (test dentinske barijere) uključena je u relevantne standarde za pretkliničku procjenu biokompatibilnosti stomatoloških materijala ISO-7405 (2).

Ova metoda testiranja zahtijeva uzgojenu trodimenzionalnu kulturu stanica kako bi se zabilježile reakcije surogat stanica pulpe. Za tu svrhu uzgojene su "besmrtne" stanice fibroblasta dobivenih od goveđe pulpe na poliamidnoj mrežici $(2,6)$. Kako bi se ovaj test više približio kliničkoj situaciji, uporabljene su "besmrtne" stanice ljudske pulpe (9) što uvelike olakšava analizu jer postoje mnogi dijagnostički markeri za ljudske stanice za razliku od govedih stanica. "Besmrtne" stanice ljudske pulpe dobivene su korištenjem SV 40 velikog $\mathrm{T}$ antigena na primarne stanice pulpe kako bi se inaktivirao p53 protein supresije tumora (9). Ekspresija broja staničnih markera bila je na jednakoj razini kod dobivenih stanica i originalnih stanica pulpe (9). Unatoč tome inicijalni pokusi pokazali su da se "besmrtne" ljudske stanice pulpe ne mogu uzgojiti na poliamidnoj mrežici kao što je slučaj s goveđim stanicama $(3,4,6)$. Stoga je svrha ovog istraživanja procijeniti pogodnost različitih hidrogelova često korištenih kod uzgoja tkiva (fibrin, kolagen i peptidi) (10) kako bi se uzgojila trodimenzionalna kultura "besmrtnih" stanica ljudske pulpe za test dentinske barijere. Uz to, ocijenjena je citotoksičnost novoga smolastog kompozitnog materijala za koji još ne postoje rezultati istraživanja primjenom testa dentinske barijere na stanicama ljudske pulpe te su rezultati uspoređeni s relevantnim kontrolnim podacima i referentnim materijalima. Osnovna hipoteza bila je (1) da su svi hidrogelovi prikladni za uzgoj stanica te da (2) citotoksičnost novog materijala nije bitno različita od referentnih vrijednosti (najčešće upotrijebljenih materijala) ostalih smolastih kompozitnih materijala.

\section{Materijali i metode}

\section{Stanice}

Korišteni su fibroblasti dobiveni iz pulpe umnjaka te su transfektirani sa SV40 velikim T antigenom (9) kako bi se postigla konstantno proliferirajuća ("besmrtna") loza stanica. Korištene su zaleđene stanice. Stanice su uzgojene na MEM $\alpha$ (GIBCO) s 20\% FCS (GIBCO). Pokus procjene hidrogelova proveden je na 48 uzgajališta. Procjena materijala provedena je na odvojenoj komori za perfuziju kako je i preporučeno za test dentinske barijere prema ISO 7405 standardima (2) (pogledaj dolje). Sve inkubacije provedene su na $37^{\circ} \mathrm{C}$ i $5 \% \mathrm{CO}_{2}$.

\section{Priprema hidrogela}

Fibrinogen iz goveđe plazme (Sigma Aldrich) otopljen je u TBS buferu (10, 15 i $20 \mathrm{mg} / \mathrm{ml}$ ) i trombinu (Sigma Aldrich) u $20 \mathrm{mM} \mathrm{CaCl}_{2}(15,100$ i $150 \mathrm{U} / \mathrm{ml})$. Jednake kolicine fibrinogena i suspenzije stanica (gustoća stanica u rasponu od $2 \times 10^{5}$ do $6.25 \times 10^{2}$ te bez stanica) pomiješane su $(60 \mu \mathrm{l}) \mathrm{i}$ rials, bovine dentin disks with varying thickness have been described as a suitable barrier simulating the in vivo situation in the mouth (4-8). Such a test method (dentin barrier test) has been included into the relevant standard for the preclinical evaluation of the biocompatibility of dental materials ISO-7405 (2).

With this test method, three dimensional cell cultures were recommended for recording cell reactions as a surrogate for the pulp tissue. For this purpose, immortalized bovine pulp-derived fibroblasts were cultured on a polyamide mesh $(2,6)$. In order to further approach the clinical situation, immortalized human pulp-derived (9) cells could be used with the additional advantage that for these cells a multitude of diagnostic cell markers are available - in contrast to bovine cells. Immortalized human pulp-derived pulp-cells have been generated by introducing the SV 40 large T antigen into primary pulp-derived cells, by which the tumor suppressor protein p53 was inactivated (9). The expression of a number of cell markers showed close similarity of the immortalized cells with those of primary pulp-derived fibroblast without immortalization (9). However, initial experiments showed that human immortalized pulp-derived cells could not be cultured on the polyamide meshes, as was successfully done with the immortalized bovine cells $(3,4,6)$. Therefore, the aim of this study was to evaluate the suitability of three different hydrogels commonly used in tissue engineering (fibrin, collagen and peptides) (10) for establishing a three-dimensional culture with immortalized human pulpderived cells to be used in the dentin barrier test. Furthermore, the cytotoxicity of a new resin-based composite material, for which data have not yet been reported, was evaluated using these new cell cultures in the dentin barrier test and compared to relevant controls and to a reference material. The underlying hypotheses were that (1) all tested hydrogels are suitable for the intended purpose and (2) the cytotoxicity of the new resin based material is not different from a reference (=commonly used) resin based filling materials.

\section{Materials and Methods}

Cells

Pulp derived fibroblasts from human wisdom teeth transfected with the SV40 large T antigen [9] were used as a continuously proliferating ("immortalized") cell-line. Cells from a frozen stock (up to passage 43) were thawed and used for the experiments. Cells were cultured in MEM $\alpha$ (GIBCO) with 20\% FCS (GIBCO). The experiments for hydrogel evaluation were performed in 48 well plates, the material evaluation in the split perfusion chamber as recommended for the dentin barrier test by ISO 7405 [2] (see below). All incubations were performed at $37^{\circ} \mathrm{C}$ and $5 \% \mathrm{CO}_{2}$.

\section{Hydrogel preparation}

Fibrinogen from bovine plasma (Sigma Aldrich) was solubilized in TBS buffer $(10,15$ and $20 \mathrm{mg} / \mathrm{ml})$ and thrombin (Sigma Aldrich) in $20 \mathrm{mM} \mathrm{CaCl}_{2}(15,100$ and $150 \mathrm{U} /$ $\mathrm{ml})$. Equal amounts of fibrinogen and the cell suspension (cell densities ranging from $2 \times 10^{5}$ to $6.25 \times 10^{2}$ and without 
korištene s poliamidnom mrežicom i bez nje. Posljedično tome, otopina trombina (dvostruko većeg volumena od fibrinogena) pomiješana je s fibinogenom uz imedijatnu gelaciju. Nakon toga gel je prekriven kulturom stanica.

Peptidni hidrogel (Puramatrix, BD Biosciences) 10mg/ $\mathrm{ml}$ pretvoren je u tekućinu u ultrasoničnoj kadici te je izmiješan u jednakim omjerima s $20 \%$ saharozom. Stanice su dodane i svaki gel $(50 \mu \mathrm{l})$ sadržavao je $10^{5}$ stanica s poliamidnom mrežicom ili bez nje. $100 \mu \mathrm{l}$ medija pažljivo je pipetirano na peptid što je izazvalo gelaciju unutar jednog sata.

Kolagenski hidrogel načinjen je od kolagena tip I iz repova štakora (BD Biosciences) koji je pomiješan s $1 \mathrm{~N} \mathrm{NaOH} \mathrm{i}$ 10 x PBS do konačne koncentracije od $3.5 \mathrm{mg} / \mathrm{ml} \mathrm{s}$ fiziološkim $\mathrm{pH}$ vrijednostima. Suspenzija stanica u mediju s različitim koncentracijama stanica u rasponu od $10^{5}$ do $1.25 \times 10^{4}$ stanica po gelu dodana je konačnom volumenu od $10 \mu \mathrm{s}$ poliamidnom mrežicom ili bez nje. Gelacija je nastupila 15 minuta nakon dodavanja stanica te je gel prekriven kulturom stanica. Inkubacija je trajala 28 dana, a medij se pritom mijenjao tri puta na tjedan $s$ tri ponavljanja za svako vrijeme inkubacije. Kako bi se procijenila optimalna gustoća uzgojenih stanica u kolagenskom hidrogelu, stanice gustoće od $1.25 \times 10^{4}$ do $10^{5}$ premještene su na mrežice i inkubirane 24 sata. Uz to, uzorci tkiva nakon 14 i 28 dana inkubacije fiksirani su u 2.5\% formalinu 24 sata i ugrađeni u Epon. Tanki uzorci obojeni su toluidinskim modrilom.

Poliamidne mrežice (Reichelt Chemietechnik, Heidelberg, Germany) korišstene su kod procjene hidrogelova i u testu dentinske barijere. ISO-7405 (2) standardi postavljeni su za mrežicu i glase: širina mrežice $150 \mu \mathrm{m}$, debljina filamenata $95 \mu \mathrm{m}$ i ukupna debljina mrežice $155 \mu \mathrm{m}$. Mrežice su izrezane u okrugle uzorke $s 0.5 \mathrm{~cm}^{2}$ površine sa svake strane. Prije uporabe, mrežice su isprane u $0.1 \mathrm{M}$ octenoj kiselini u trajanju od 30 min i 5 puta isprane destiliranom vodom.

\section{Procjena hidrogela}

Mehanička stabilnost gelova ocijenjena je dovoljnom ako je gelove bilo moguće transportirati bez uništavanja iz posudica do odijeljene komore za perfuziju za test dentinske barijere. Skvrčavanje i degradacija gela ocijenjena je vizualno uz pomoć invertiranog mikroskopa nakon različitih razdoblja inkubacije.

Vitalitet stanica u kulturi stanica ocijenjen je MTT testom i WST-1 testom proliferacije stanica. MTT test preporučen je u ISO-7405 standardima za test dentinske barijere (2). Nakon uklanjanja površinskog sloja medija, $100 \mu \mathrm{l}$ MTT otopine (Sigma Aldrich) dodano je kulturama stanica i inkubirano 2 sata. Stanice su nakon toga razrijeđene s 200 $\mu \mathrm{l}$ DMSO i $100 \mu \mathrm{l} / \mathrm{gel}$ je prenesen na 96 pločica. Razvoj boje određen je fotometrijski na $540 \mathrm{~nm}$. Nakon toga WEST-1 reagent (Roche) pomiješan je $s 5 \mathrm{ml}$ odgovarajuće otopine elektrolita te je $10 \mu \mathrm{l}$ u $90 \mu \mathrm{l}$ kulture pipetirano na gel nakon što je uklonjena originalna kultura. Nakon 2 sata inkubacije, uzorci su protreseni 5 minuta $(100 / \mathrm{min})$ te je $100 \mu \mathrm{l}$ s povr- cells) were mixed $(60 \mu \mathrm{l})$ and used with and without a polyamide mesh. Subsequently, the thrombin-solution (twice the volume of fibrinogen) was mixed with fibrinogen and gelation occurred immediately. The gel was then overlaid with culture medium.

For the peptide hydrogel (Puramatrix, BD Biosciences) $10 \mathrm{mg} / \mathrm{ml}$ was liquefied in an ultrasonic bath and then mixed in equal amounts with $20 \%$ sucrose. Cells were added and each gel $(50 \mu \mathrm{l})$ contained $10^{5}$ cells, again with and without the polyamide mesh. $100 \mu \mathrm{l}$ of culture medium was carefully pipetted on the peptide which led to a gelation within one hour.

For the collagen hydrogels, type I collagen from rat tails (BD Biosciences) was mixed with $1 \mathrm{~N} \mathrm{NaOH}$ and $10 \times \mathrm{PBS}$ to a final concentration of $3.5 \mathrm{mg} / \mathrm{ml}$ at physiological $\mathrm{pH}$. Cell suspensions in culture medium with different cell concentrations resulting in final cell numbers ranging from $10^{5}$ to $1.25 \times 10^{4}$ cells per gel were added to a final volume of $10 \mu \mathrm{l}$ with or without a polyamide mesh. Gelation occurred within 15 minutes and then the gel was overlaid with culture medium. Incubation time was up to 28 days with culture medium replacement three times a week with three replicates for each incubation time. In order to define the optimal cell seeding density in the collagen hydrogel, cells numbers ranging from $1.25 \times 10^{4}$ to $10^{5}$ were seeded onto the meshes and incubated for 24 hours. Additionally, tissue samples after 14 and 28 days of incubation were fixated in $2.5 \%$ formalin for $24 \mathrm{~h}$ and embedded in Epon. The semi-thin sections were stained with toluidine-blue.

Polyamide meshes (Reichelt Chemietechnik, Heidelberg, Germany) were used for both the evaluation of the hydrogels and in the dentin barrier test. Specifications are given in ISO-7405 [2]: mesh width: $150 \mu \mathrm{m}$, thickness of the filaments of $95 \mu \mathrm{m}$ and a total thickness of the mesh: $155 \mu \mathrm{m}$. The meshes were cut into round samples with $0.5 \mathrm{~cm}^{2}$ surface on each side. Before use, the meshes were cleaned for 30 minutes in $0.1 \mathrm{M}$ acetic acid and then rinsed in distilled water 5 times.

\section{Hydrogel evaluation}

Mechanical stability of the gels was regarded sufficient if the gel could be transported without destruction from the 48-well plates to the split perfusion chamber of the dentinbarrier-test. Contractions of the gels or degradation were evaluated visually under an inverted microscope after different periods of incubation for any changes of form.

Cell viability of the cultures was evaluated using the MTTassay and the WST-1 cell proliferation assay. The MTT-test is recommended in ISO-7405 for the dentin barriers test (2). Briefly after the removal of the supernatant cell culture medium, $100 \mu$ l of MTT solution (Sigma Aldrich) was added to the cultures and incubated for 2 hours. Cells were then solubilized with $200 \mu \mathrm{L}$ DMSO and $100 \mu \mathrm{l} /$ gel was transferred to a 96-well plate. Color development was determined photometrically at $540 \mathrm{~nm}$. Accordingly, WEST-1 reagent (Roche) was mixed with $5 \mathrm{ml}$ of the corresponding electrolyte solution and $10 \mu \mathrm{l}$ in $90 \mu \mathrm{l}$ culture medium were pipetted onto the gels, after the original culture medium had been removed. 
šine otopine preneseno na 96 pločica. Fotometrijska mjerenja provedena su na $450 \mathrm{~nm}$. Optimalna inicijalna gustoća rasta stanica u kolagenskom hidrogelu na poliamidnoj mrežici ocijenjena je mikroskopski, a kriterij za optimalnu gustoću stanica bio je najmanji broj stanica i nedostatak praznih prostora između stanica (uniformni sloj stanica) između filamenata mrežice.

\section{Test dentinske barijere}

Test je proveden prema ISO 7450 standardima (2). Stanice su unesene u kolagenski hidrogel na poliamidnoj mrežici kao što je opisano te su inkubirane dva tjedna sa zamjenskim medijem tri puta na tjedan. Dentinski diskovi pripremljeni su iz donjih prednjih goveđih zubi kao što je drugdje opisano (2) i upotrijebljene su $200 \mu \mathrm{m}$ debele ploške dentina bliže pulpi. Ploške dentina i trodimenzionalne kulture stanica stare dva tjedna stavljene su na difuzijsku komoru (Minucells\&Minutissues, Bad Abbach, Germany) kao što je i preporučeno u ISO 7495 standardima (2). Komora je prožeta medijem u trajanju od 24 sata sa $0.3 \mathrm{ml} / \mathrm{h}$. Nakon toga stomatološki su materijali aplicirani na drugoj strani dentinskog diska te je perfuzija nastavljena sljedećih 24 sata. Uzorci su pažljivo uklonjeni iz komore te je zabilježena reakcija stanica primjenom WST-1 testa.

\section{Testirani materijali}

Testirani materijali, proizvođači i serijski brojevi nabrojeni su u tablici 1. Dva smolasta kompozitna materijala - jedan često korišten referentni materijal (Tetric EvoCeram) i testirani materijal (N'Durance) aplicirani su bez često uporabljenog samojetkajućeg adheziva u dvjema bočicama (Clearfil SE Bond). Negativna kontrola (netoksična kontrola) i pozitivna kontrola (mrežice bez stanica) te toksični referentni materijal (standardni toksični materijal) upotrijebljeni su u skladu s ISO 7450 standardima (2). Smolasti kompozitni materijal i dentinski adhezivi polimerizirani su 30 sekundi polimerizirajućom lampom (Optilux 400, Demetron, Danbury, SAD) jakosti od $699 \mathrm{~mW} / \mathrm{cm}^{2}$ (mjereno s: Dentsply, Curerite, 644726).

\section{Obrada podataka}

Za test dentinske barijere provedena su tri nezavisna eksperimenta $s$ ponavljanja za svaki materijal (uključujući kontrole). Za svaki eksperiment fotometrijska očitanja ma-
After 2 hours incubation, the cultures were shaken for $5 \mathrm{~min}$ utes $(100 / \mathrm{min})$ and then $100 \mu \mathrm{l}$ of the supernatant was transferred to a 96-well plate. Photometric measurements were performed at $450 \mathrm{~nm}$. Optimal initial cell seeding density in collagen hydrogels on the polyamide meshes was evaluated microscopically and the criterion for optimal cell density was the smallest cell number but the lack of cell voids (confluent cell layer) between the filaments of the meshes.

\section{Dentin barrier test}

The test was performed according to ISO 7405 [2]. Briefly, the test cells were seeded in the collagen hydrogel on the polyamide mesh as described above and then incubated for two weeks with culture medium replacement three times per week. Dentin disks from lower anterior bovine front teeth were prepared as described elsewhere [2] and $200 \mu \mathrm{m}$ thick slices closest to the pulp were used. The dentin slices and the two weeks three-dimensional cultures were mounted into the split-diffusion chamber (Minucells\&Minutissues, Bad Abbach, Germany), as recommended by ISO 7495 [2]. The chamber was perfused with culture medium for 24 hours at $0.3 \mathrm{ml} / \mathrm{h}$. Then the test materials were applied on the other side of the dentin disk according to the instructions of the manufacturers and the system was incubated for another 24 hours with the same perfusion. The cultures were carefully removed from the split perfusion chamber and the cell reaction was recorded using the WST-1 assay as described above.

\section{Test materials}

The tested materials, manufacturers and Lot-numbers are listed in Table 1. The two resin-based composites - one commonly used reference material (Tetric EvoCeram) and the test material (N'Durance) were applied with and N'Durance also without a commonly used two-bottle self-etch adhesive (Clearfil SE Bond). Negative controls (non-toxic control) and positive controls (Meshes without cells) as well as a toxic reference material (standard toxic material) were used according to ISO 7405 [2]. The resin based composites and the dentinal adhesives were light-cured for 30 seconds with a light curing unit (Optilux 400, Demetron, Danbury, USA) with an irradiance of $699 \mathrm{~mW} / \mathrm{cm}^{2}$ (measured with: Dentsply, Curerite, 644726).

\section{Data treatment}

For the dentin barrier test three independent experiments were performed with 4 replicates for each material (including controls). For each experiment, photometrical read-

\begin{tabular}{|c|c|c|}
\hline Ime materijala $\bullet$ Material name & Proizvođač $\bullet$ Manufacturer & Cat-No., Lot-No. \\
\hline Clearfil SE Bond & Kuraray & Cat: 0141015 , LOT 1889AA \\
\hline Clearfil SE Primer & Kuraray & Cat: 6289201, LOT 1008AA \\
\hline Tetric EvoCeram & Ivoclar Vivadent & Cat: 0172128, LOT N26104 \\
\hline N’Durance Dimer Flow & Septodont & Cat: 0358305, LOT 072909A \\
\hline $\begin{array}{l}\text { Negative control: } \\
\text { Président Regular }\end{array}$ & Coltène AG & Cat: 0111HK4, LOT 0125251 \\
\hline Positive control material & According to ISO 7405 [2] & \\
\hline
\end{tabular}


terijala usporedena su s negativnom kontrolom $(=100 \%)$ is mrežicama bez stanica $(=0 \%)$ te su iskazana kao postotak relativnog rasta. Podaci su predstavljeni kao srednje vrijednosti s 25/75 postotcima. Provedena je statistička analiza primjenom neparametrijskog Kruskal-Wallisova testa (U-test). Razina značajnosti određena je na $\mathrm{p} \leq 0.05$.

\section{Rezultati}

\section{Procjena hidrogela}

Fibrinski i peptidni hidrogel s poliamidnom mrežicom ili bez nje bili su oštećeni tijekom transfera kulture stanica na komoru za prožimanje tako da možemo govoriti o neadekvatnoj mehaničkoj stabilnosti gelova. Uz to, velike količine stanica $\left(2 \times 10^{5}\right.$ to $\left.5 \times 10^{4}\right)$ uzrokovale su propadanje fibrinskog gela 5 dana nakon inkubacije. Isto tako fibrinski i peptidni hidrogelovi nisu se potpuno otopili u DMSO (MTT test) te nastali podaci nisu bili ponovljivi (WST-1). Stoga je procjena reakcije stanica primjenom MTT ili WST-1 testa bila problematična za dva hidrogela.

Istodobno, kolagenski hidrogel pokazao se mehanički stabilnim gelom. Kolagenski gel se kontrahirao ovisno o broju stanica. Pregled svjetlosnim mikroskopom pokazao je da se već s brojem stanica od $2 \times 10^{5}$ i 5 dana nakon inkubacije, gel kontrahirao. Manji brojevi stanica nisu prouzročili mikroskopski vidljivo sakupljanje ni 14 dana nakon inkubacije. MTT test nije bilo moguće provesti zbog toga što se gel nije dovoljno otopio. Unatoč tome, WST-1 test bilo je moguće provesti te je test pokazao linearnu ovisnost fotometrijskog mjerenja broja stanica u rasponu od 12500 do 100000 stanica po gelu (podatci nisu prikazani) s koeficijentom korelacije od $\mathrm{r}^{2}=0.9$.

Optimalna gustoća stanica na kolagenskom gelu određena je izravno ispod preokrenutog mikroskopa nakon 24 sata inkubacije. S inicijalnom gustoćom stanica od $5 \times 10^{4}$ i podjednakom distribucijom stanica (Slika 1) bez praznih prostora na mrežici. Kinetika rasta pod tim okolnostima pokazuje kontinuirani rast stanica do 10 dana nakon inkubacije, zatim slijedi plato/ stagnacija do 21 dana nakon inkubacije i nakon toga pad u broju stanica (Slika 2). Histološki uzorci (28 dana nakon inkubacije) pokazuju trodimenzionalnu višeslojnu kulturu stanica između filamenata mrežice (Slika 3). ings of the materials were related to the negative control (= $100 \%)$ and the meshes without cells $(=0 \%)$ and expressed as $\%$ relative growth. Data are presented as medians with 25/75 percentiles. Statistical analysis was performed using the nonparametrical Kruskal-Wallis-test (U-test). The level for significance was set to $\mathrm{p} \leq 0.05$.

\section{Results}

\section{Hydrogel evaluation}

For the fibrin and the peptide hydrogels with and without the polyamide mesh the cultures could not be transferred from the culture plate to the split perfusion chamber without the destruction of the gels, thus the mechanically stability was considered insufficient. Furthermore, high cells numbers $\left(2 \times 10^{5}\right.$ to $\left.5 \times 10^{4}\right)$ caused fibrin gel degradation after 5 days of incubation. Also, the fibrin and peptide gel could not be sufficiently dissolved in DMSO (MTT assay) or generated data were not reproducible (WST-1 assay). Therefore, the evaluation of cell reaction using the MTT or the WST-1 assay was problematic in these two types of hydrogels.

In contrast, the collagen hydrogel proved to have sufficient mechanical stability. Depending on the cell number, collagen gels contracted. Light microscopy observations, however, showed that only with a cell number of $2 \times 10^{5}$ after 5 days of incubation, a visible contraction occurred. Lower cell numbers did not cause microscopically detectable contraction after 14 days of incubation. The MTT assay could not be performed, because the gel could not be sufficiently dissolved. However, the WST-1 assay could be performed showing a linear relation of the photometric reading on the cell numbers ranging from 12500 to 100000 cells per gel (data not shown) with a correlation coefficient of $\mathrm{r}^{2}=0.9$.

Optimal cell seeding density for the collagen gels was determined directly under the inverted microscope after $24 \mathrm{~h}$ incubation time. With an initial cell density of $5 \times 10^{4}$ an even distribution of the cells (Fig. 1) with no empty spaced between the meshes could be observed. Growth kinetics under these conditions (three replicates for each time point) show an continuous cell growth until an incubation time of 10 days, then a plateau phase until day 21 was observed and then a decline in cell numbers (Fig. 2). The histological sections (28 days of incubation) show a three-dimensional multi-layer culture between the mesh filaments (Fig. 3).

Tablica 2. Rezultati statističke obrade podataka testa dentinske barijere (Kruskal-Wallisova jednosmjerna neparametrijska analiza
$\begin{aligned} & \text { varijabilnosti) } \mathrm{ns}=\text { nije značajno, } \mathrm{s}=\text { značajno }(\mathrm{p} \leq 0.05) \\ & \text { Table } 2\end{aligned}$
$\begin{aligned} & \text { Results of statistical evaluation of the dentin barrier test (Kruskal-Wallis One-way nonparametric Analysis of Variance) ns = not } \\ & \text { significant, } \mathrm{s}=\text { significant }(\mathrm{p} \leq 0.05)\end{aligned}$



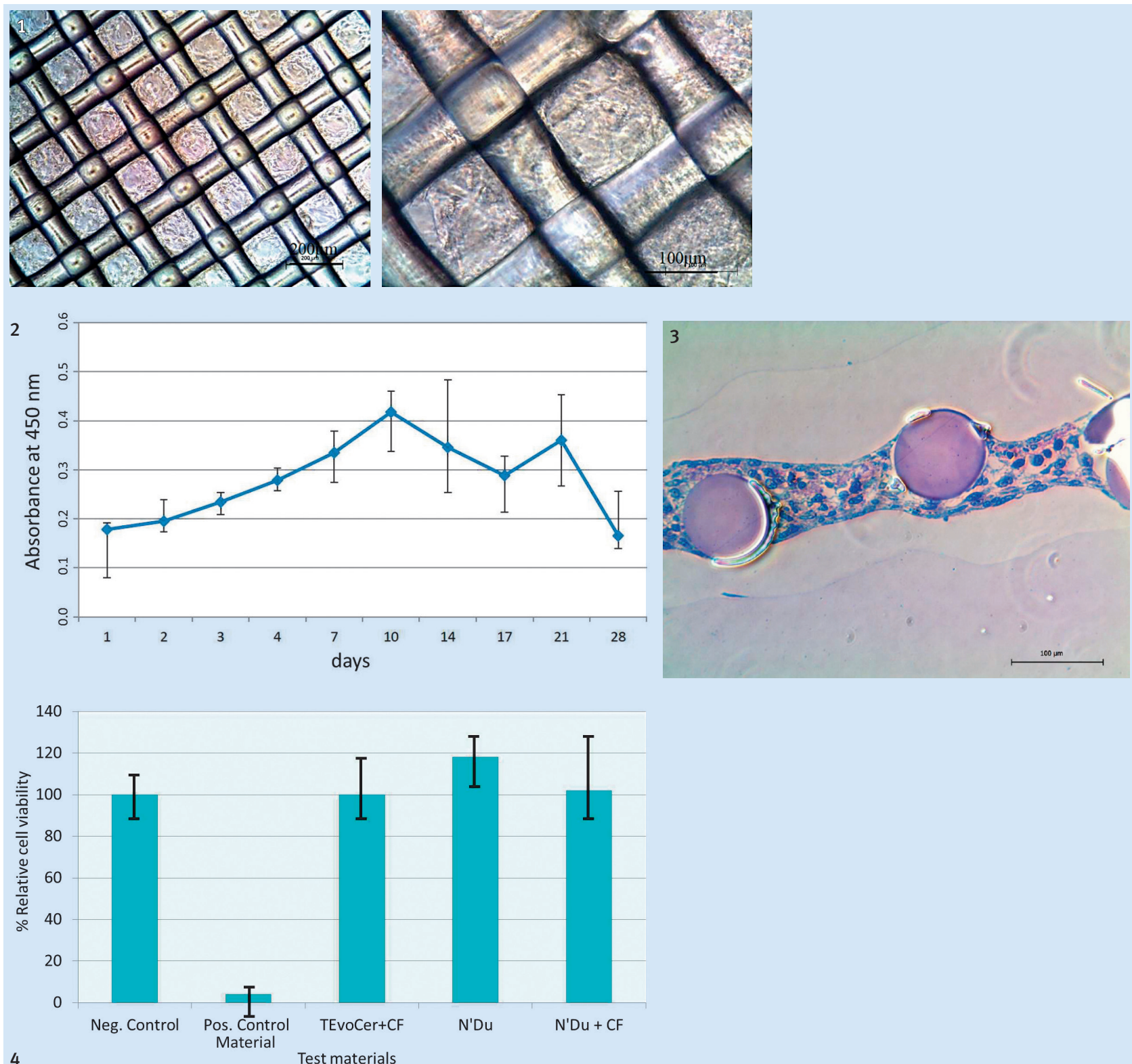

Slika 1. Mikroskopska procjena distribucije stanica u kolagenu na poliamidnoj mrežici 24 sata nakon inkubacije $s$ inicijalnom gustoćom stanica od $5 \times 10^{4}$ : podjednaka distribucija stanica bez praznina (lijevo $10 x$, desno $25 \times$ povećanje).

Figure 1 Microscopic evaluation of the cell distribution in collagen on the polyamide mesh after $24 \mathrm{~h}$ incubation time with an initial cell density of $5 \times 10^{4}$ : an even distribution of the cells without voids could be observed (left 10x, right 25x magnification)

Slika 2. Kinetika rasta $(n=3$, srednja vrijednost s min i max) "besmrtnih" stanica ljudske pulpe u kolagenskom hidrogelu s poliamidnom mrežicom. Vidljiv kontinuirani rast stanica do dana 10, nakon toga slijedi plato do dana 21, nakon čega slijedi pad u broju stanica.

Figure 2 Growth kinetics ( $n=3$, medians with min and max) of immortalized human pulp-derived cells in a collagen scaffold with a polyamide mesh show an continuous cell growth until day 10 , then a plateau phase until day 21 occurs and then a decline in cell numbers

Slika 3. Histološki preparat (poprečni presjek) obojen toulidinskim modrilom (28 dana nakon inkubacije) pokazuje trodimenzionalnu višeslojnu kulturu stanica između slojeva mrežice (250x povećanje)

Figure 3 Histology (cross section) stained with toluidine-blue (28 days of incubation) showing a three-dimensional multi-layer culture between the meshes (250x magnification)

Slika 4. Rezultati testa dentinske barijere s trodimenzionalnim kulturama stanica dobivenih iz ljudske pulpe (srednja vrijednost s $25 / 75$ postocima, $n=12$ ); za testirane materijale vidi Tablicu 1

Figure 4 Results from the dentin barrier test with three-dimensional cultures of human pulp-derived cells (medians with 25/75 percentiles, $n=$ 12); for test materials see Table 1 


\section{Test dentinske barijere}

Rezultati testa dentinske barijere prikazani na Slici 4. Nisu zabilježene statistički značajne razlike između rezultata za dva smolasta kompozita s dentinskim adhezivom ili bez njega i netoksičnog kontrolnog materijala. Istodobno, statistički značajna razlika zabilježena je između testiranih materijala ili netoksične kontrole toksičnoga standardnog referentnog materijala (Tablica 2).

\section{Rasprava}

\section{Hidrogelovi}

Prvotni cilj istraživanja bio je testirati tri različite hidrogelske podloge često primjenjivane u laboratorijskom razvoju tkiva (10) i njihovu sposobnost da uzgoje "besmrtne" fibroblaste iz pulpe u trodimenzionalnom mediju koje se upotrebljavaju u testu dentinske barijere opisanom u ISO 7405 (2). Hidrogelovi bazirani na fibrinu i peptidu, uporabljeni u ovom istraživanju, odbačeni su zbog nezadovoljavajućih mehaničkih svojstava. Unatoč općoj pogodnosti tih podloga za uzgoj stanica (10), mehanička svojstva podloga igraju važnu ulogu u ovom istraživanju zato što se uzgojeni uzorci moraju neoštećeni prenijeti u razdvojenu perfuzijsku komoru radi provođenja testa dentinske barijere. Mehanička svojstva takvih konstrukcija uzgojenih stanica ne samo da ovise o tipu hidrogela nego i o vremenu inkubacije te o vrsti stanica koje se uzgajaju (11). Slaba mehanička svojstva pripisuju se fibrinskom hidrogelu (12) pri čemu ni korištenje poliamidne mrežice nije poboljšalo situaciju. Drugi razlog nekorištenja fibrinskog i peptidnog hidrogela jest taj što reakcija stanica u tim hidrogelovima nije mogla biti ocijenjena primjenom uobičajenih testova vitaliteta kao što je MTT ili WST-1 test. Modifikacija testova vitaliteta, primjerice mijenjanje otapala (13), nije dalje obrađena zbog slabih mehaničkih svojstava tih dvaju hidrogelova.

$S$ druge strane, tip I kolagen korišten u ovom istraživanju pokazao se kao pogodan materijal za tu svrhu. Sveopća pogodnost kolagena (posebno tip I) kao skele za laboratorijski uzgoj tkiva već je dugo poznata činjenica (10). Jedan razlog tome je što kolagen daje kemijske i strukturalne informacije prirodne izvanstanične matrice (VSM) (14). Kolagen je isto tako opisan u istraživanjima kao superiornija matrica za uzgoj diferencirane dentalne matične stanice (15).

Kolagen se biorazgrađuje uz pomoć enzima (10) ali u ovom slučaju taj proces nije ugrozio namjeru ovog istraživanja. Kinetika rasta (Slika 2) pokazala je konstantno povećanje vitaliteta stanica za vrijeme prvih 10 dana nakon inkubacije sve do platoa/stagancije nakon 21 dana. Nakon toga razdoblja pad u vitalitetu stanica može upućivati na početak raspadanja kolagenske matrice. Za test dentinske barijere ukupno vrijeme rasta stanica je uglavnom kraće od tri tjedna. Zanimljivo je da se kolagenski hidrogel koji sadržava stanice fibroblasta uglavnom skvrčava (16). To ovisi o koncentraciji kolagena i broju stanica (17). U ovom istraživanju, u kojem je broj stanica manji od $2 \times 10^{5}$ do 14 dana nakon inkubacije, nije zapaženo mikroskopsko skvrčavanje. Test proliferacije stanica, proveden za razdoblje inkubacije do 28 dana, pokazao je smanjenje u vitalitetu kulture stanica samo nakon

\section{Dentin barrier test}

Results of the dentin barrier test are shown in Fig. 4. No statistically significant difference could be observed between the results for the two resin-based composites with or without the dentinal adhesive and the non-toxic control material. On the other side, statistically significant differences were observed between the test materials or the non-toxic control and the toxic standard reference material (see Table 2).

\section{Discussion}

\section{Hydrogels}

The first aim of this study was to test three different hydrogel based scaffolds - commonly used in tissue engineering (10) - for their suitability to grow human immortalized pulp-derived fibroblast in three dimensional cultures, which are then to be used in the dentin barrier test as described in ISO 7405(2). Fibrin and peptide based hydrogels as used here were discarded primarily because of their insufficient mechanical properties. Despite the general suitability of these scaffolds for tissues engineering (10), mechanical properties play a special role here due to the fact that the cell scaffold constructs have to be transferred from the culture plate for growth to the split perfusion chamber for the dentin barrier test. Mechanical properties of such constructs are not only dependent upon the hydrogel type, but also on the incubation times required and upon the cell types (11). Poor mechanical properties have also been described for fibrin (12), and the additional support by the polyamide mesh did not sufficiently improve the stability. A second reason for not using fibrin and peptide based hydrogels was the fact that cell reactions in these hydrogels could not be evaluated using commonly used viability tests such as the MTT or the WST-1 assay as described above. Modifications of the vitality test, e.g. by changing solvents (13) were not further followed because of the poor mechanical properties of the two hydrogels.

On the other hand, type I collagen as used in this study proved to be suitable for the given purpose. The general suitability of collagen (especially type I) as scaffold for tissue engineering has long been known (see survey in (10)). One reason is that collagen offers chemical and structural information of the natural extracellular matrix (ECM) (14). Collagen type I has also been described to be superior to other scaffolds (gelatin or chitosan) for cultivating and differentiating dental stem cells (15).

Collagen is biodegraded by enzymes (10), but this process apparently does not impair the suitability of collagen I for the purposes described here. Growth kinetics (Fig. 2) showed a constant increase of cell vitality for the first ten days with a plateau up to 21 days. Only after that period, a decline of cell vitality may indicate degradation of the scaffold. For the dentin barrier test the total time for cells growth and test is normally less than three weeks. Another point of interest is that constructs of collagen hydrogels containing (fibroblastic) cells are known to contract [16]. This is dependent on the collagen concentration and the cell number (17). In this study, with a cell number of less than $2 \times 10^{5}$ up 
tri tjedna od inkubacije. Sva moguća skvrčavanja kolagenske matrice nisu utjecala na njegov integritet sve do trećeg tjedna. Histološkim pregledom ustanovljena je višeslojna trodimenzionalna kultura stanica čak i 28 dana nakon inkubacije.

WST-1 test je bio tehnički jednostavan za izvođenje koristeći se stanicama iz kolagenskog hidrogela te je pokazao linearni odnos fotometrijskog očitanja $s$ gustoćom stanica za brojeve stanica relevantne u testu dentinske barijere. Stoga se WST-1 test smatra pogodnim za procjenjivanje reakcije stanica. MTT i WST-1 testovi temeljeni su na korištenju tetrazolinskih soli koje se metabolički reduciraju u obojene proizvode nazvane formazani (18). Za razliku od MTT-a, redukcija WST-1 (druga generacija tetrazolinskih soli) u topljivi formazan je proces koji je povezan s ekstracelularnom matricom ili membranom stanica (18). Stoga raspad stanica i otapanje netopljivog MTT formazana nije potrebno i WST-1 test čini boljim izborom za ovu vrstu hidrogela.

Zbog navedenih razloga možemo odbaciti hipotezu da sva tri testirana hidrogela možemo upotrijebiti kao matricu za uzgoj stanica. Kolagen se pokazao kao odgovarajuća matrica zajedno s poliamidnom mrežicom za uzgoj stanica koje će se upotrebljavati u testu dentinske barijere. Prednosti korištenja ljudskih stanica jest $\mathrm{u}$ tome što one vjernije dočaravaju kliničku situaciju te je razvijeno mnogo analitičkih alata za istraživanje stanične biologije na stanicama štakora ili ljudi.

\section{Testirani materijali}

Podatci za netoksične kontrolne materijale i za standardnu toksičnu kontrolu u skladu su s rezultatima testa dentinske barijere u kojem su upotrijebljene "besmrtne" stanice goveđe pulpe u trodimenzionalnoj kulturi stanica. Testirani samojetkajući adheziv (Clearfil SE Bond) pokazao se blago toksičnim u testu dentinske barijere s $500 \mu \mathrm{m}$ debelim diskovima dentina i goveđim stanicama pulpe (8). U ovom slučaju testiranje je bilo usmjereno ispitivanju vezivanja adheziva bez kompozita što je moglo utjecati na reakciju.

Autori Kim et al. (20) također su ispitivali Clearfil SE Bond samostalno testom dentinske barijere te su za rezultate dobili redukciju vitaliteta stanice oko $50 \%$ za dentinske diskove debljine $500 \mu \mathrm{m}$. U tom istraživanju uporabljene su druge stanice (L-929 mišji fibroblast) te kontrola nije sadržavala (netoksični) materijal koji bi utjecao na tehničku manipulaciju kultura za vrijeme eksperimenta i na adheziv nije stavljan smolasti kompozit. $\mathrm{U}$ istom istraživanju rezultati za toksični referentni standardni materijal (Tetric EvoCeram) $s$ dentalnim adhezivom nisu pokazali nikakvu toksičnu staničnu reakciju. Ti su rezultati u skladu s rezultatima drugih istraživanja (21) u kojima nisu zabilježene toksične reakcije nakon korištenja Tetric EvoCeram kompozita na testu uporabom "besmrtne" govede stanice pulpe iako je u tom istraživanju uporabljen drugi samojetkajći adheziv (Excite). Sve u to 14 days of incubation no contraction could be observed microscopically. The cell proliferation assay conducted with an incubation period of up to 28 days showed a decrease of culture vitality only after the third week. Apparently, any possible contraction of the collagen cell construct did not influence the suitability of the construct until the third week. Histology confirmed the presence of a multilayer three dimensional culture even after a 28 days incubation period.

The WST-1 assay was technically easy to perform with cells in the collagen hydrogels and showed a linear relation of the photometric reading with the seeded cell density for cell numbers relevant in the dentin barrier test. Therefore, the WST-1 assay was considered suitable for the evaluation of the cell reaction. Both, the MTT and the WST-1 assay are based on the use of tetrazolium salts that are metabolically reduced to highly colored end products called formazans [18]. In contrast to MTT, the reduction of WST-1 (so-called second generation tetrazolium salts) into soluble formazan is apparently extracellular or plasma membrane associated [18]. Therefore, the cell disruption and solubilization of insoluble MTT-derived formazan are not necessary, which apparently makes the WST-1 assay more suitable for these hydrogel cell constructs than the MTT assay.

Due to the reasons mentioned above, the hypothesis that all three tested hydrogels under the given conditions are suitable as cell carriers has to be rejected. Collagen proved to be a suitable cell scaffold used together with a polyamide mesh for cultures to be used in the dentin barrier test. Advantages of cells from human origins are that they are closer to the clinical situation and with those cells a multitude of analytical tools developed for cell biology, which are mainly developed to be used for cells from rodents or humans, can be applied.

\section{Test Materials}

Data for the non-toxic control material, and for the standard toxic control are in accordance with data from the dentin barrier test using immortalized bovine pulp-derived cells in three dimensional cultures (19). The tested dentinal self-etch adhesive (Clearfil SE Bond) proved to be slightly toxic in the dentin barrier test with $500 \mu \mathrm{m}$ dentin disks using bovine derived pulp cells (8). However, the dentinal bonding was tested alone without a composite, which might influence the reaction. Kim et al. (20) also tested Clearfil SE Bond alone in a dentin barrier test and showed approximately $50 \%$ of reduction of cell viability for $500 \mu \mathrm{m}$ dentin disks. However, other cells were used by Kim et al. (L-929 mouse fibroblasts) and the control did not involve the placement of a (non-toxic) material showing the influence of the technical manipulations of the cultures during the experiment and again no composite resin was placed on top of it. In this study, data for the reference standard material (Tetric EvoCeram) used with a dentinal adhesive showed no toxic cellular reaction. This is in agreement with non-toxic reactions observed with TetricEvCeram in the same test using immortalized bovine pulp-derived cells (21), although another self-etch dentinal adhesive (Excite) was used in those experiments. Altogether, these data indicate that the use of immortalized human derived pulp cells render similar re- 
svemu, rezultati upućuju na to da "besmrtne" ljudske stanice pulpe daju iste rezultate kao i govede stanice pulpe kada je postava eksperimenta ista.

Rezultati za novi restaurativni materijal (N’Durance) nisu pokazali toksičnu reakciju sa samojetkajućim adhezivom ili bez njega. U literaturi još nisu zabilježene reakcije stanica na taj materijal. Testirani materijal sadržava, umjesto bisGMA, novi smolasti materijal koji se temelji na kiselom dimeru dimetakrilata (22) za koje je dokazano da imaju veću konverziju dvostruke veze nego uobičajeni dimetakrilatni monomeri $(22,23)$. Nadalje, etoksirani bisfenol A dimetakrilat (bis-EMA) i uretan dimetakrilat (UDMA) dio su faze stvrdnjavanja smole na što otpada otprilike $40 \%$ materijala (podatci proizvođača). U usporedbi s ostalim smolastim kompozitima, N'Durance je iznimno hidrofobni materijal te je pokazao niske vrijednosti topljivosti u destiliranoj vodi (24). Ti su podatci u skladu s netoksičnim reakcijama u ovom istraživanju.

Druga hipoteza u ovom istraživanju ne može biti odbijena zbog toga što referentni materijali nisu proizveli jednak stanični odgovor kao i materijali u testu dentinske barijere. Primjena rezultata testa $\mathrm{u}$ istraživanju na kliničke slučajeve često je vrlo problematična (1). Unatoč tome test dentinske barijere koji se koristi trodimenzionalnim kulturama stanica iz pulpe, pokazao je određenu korelaciju $s$ rezultatima ovog istraživanja i podataka dobivenih primjenom materijala na govede stanice $(4,6)$. Stoga podatci pokazuju da se od testiranog materijala ne očekuje oštećenje pulpe ako je prekrivena slojem intaktnog dentina.

\section{Zaključak}

Ljudske "besmrtne" stanice pulpe tretirane SV40 velikim T antigenom mogu uspješno poslužiti kao trodimenzionalne kulture stanica u testu dentinske barijere ako se primjenjuje tip I kolagenski hidrogel. Testirani materijal (N’Durance) ne bi trebao izazvati reakciju pulpe ako pulpa nije eksponirana.

\section{Priznanje}

Zahvaljujemo Institutu za Patologiju, Sveučilište u Regensburgu zbog asistiranja kod histoloških preparata.

\section{Sukob interesa}

Autori izjavljuju da ne postoji sukob interesa. Materijale je dostavio proizvođač. sults as those derived from bovine cells in the same test device.

Data for the new restorative material (N'Durance) showed no cytotoxic reaction both with and without the use of a self-etch dentinal adhesive. No other reports in the literature on the cell reaction towards this material have been available, so far. The test material contains instead of bisGMA a new resin based on dimer acid-based dimethacrylates (22), which were proven to have a significantly higher final double-bond conversion than common dimethacrylate monomers $(22,23)$. Furthermore, ethoxylated bisphenol A dimethacrylate (bis-EMA) and urethane dimethacrylate (UDMA) are part of the resin phase, which altogether amounts to $41 \%$ of the material (manufacturer information). In comparison with other resin based composites, N'Durance being a strongly hydrophobic material showed a low solubility in distilled water (24). These data are in line with the non-toxic reaction found in this study.

The second hypothesis of this study that the test and the reference materials elicit the same cell reaction in the dentin barrier test cannot be rejected. The extrapolation of data from cell culture experiments to the patient situation is generally very problematic (1). However, for the dentin barrier test using three dimensional cultures of pulp-derived cells, a good correlation of results from this test and clinical data has been shown for a limited number of materials with bovine cells $(4,6)$. Therefore, the results for the test material indicate that in the clinical situation no pulp damage is expected if the pulp is covered with an intact dentin layer.

\section{Conclusions}

Human SV40 Large T antigen immortalized pulp-derived cells can be successfully used as three dimensional cultures in the dentin barrier test using additionally a collagen type I hydrogel. The tested material (N'Durance) is not likely to evoke a pulp response if pulp exposure is avoided.

\section{Acknowledgement}

We thank Mr. H. I. Siegmund (BTA) from the Institute for Pathology, University of Regensburg for the assistance with the histology (preparation, semi-thin sections and staining).

\section{Conflict of Interest}

The authors declare that they have no conflict of interest. The test material was provided by the manufacturer. 


\section{Abstract}

Objectives: So far, bovine immortalized pulp cells have been used as three dimensional cultures for cytotoxicity testing of filling materials in the dentin barrier test (DBT). In this study, the use of human pulp-derived cells was evaluated, which would better simulate the clinical situation, and a composite material with a new resin base was tested. Materials and Methods: SV40-transfected human pulp cells (tHPC) were cultured in hydrogels (fibrin, peptide, collagen) and mechanical properties and cell viability (MTT or WST-1) were determined. For cell cultures in collagen, a four week - proliferation assay was performed (WST-1). After 14 days of three-dimensional culture in collagen, tHPC were introduced into the DBT with $200 \mu \mathrm{m}$ dentin disks. After a 24-hour incubation under perfusion $(0.3 \mathrm{ml} / \mathrm{h})$, the following materials were applied according to the manufacturers' instructions (1) President (Coltene): negative (non-toxic) control, (2) CaGPG14 (ISO 7405): positive (toxic) control, (3) Tetric EvoCeram (Ivoclar Vivadent) with Clearfil SEBond (Kuraray, reference material), (4) N`Durance (Sepodont, test material), (5) N`Durance with Clearfil SEBond. Cell viability was determined after 24-hour incubation (WST-1). The percentage of relative viability was calculated (negative control $=100 \%$ ) and statistically analyzed (Kruskal-Wallis-test, $\mathrm{p} \leq 0.05$ ). Results: Fibrin and peptide gels had insufficient mechanical properties for the DBT. Collagen appeared suitable for three-dimensional cell culture of tHPC for up to 21 days. The cultures could be transferred to the DBT device and results for controls were similar to previous tests with bovine cells. The DBT using tHPC in the collagen showed no statistically significant difference between the test material with and without the adhesive and the reference resin composite. Conclusions: tHPC in collagen can replace bovine cells in the DBT. The tested filling material is not likely to cause pulp damage, if the pulp is covered by an intact dentin layer.
Received: May 30, 2014

Accepted: June 16, 2014

Address for correspondence Professor Gottfried Schmalz University of Regensburg Department of Operative Dentistry and Periodontology 93042 Regensburg, Germany Tel. 0941-9444980

Fax. 0941-9444981 Gottfried.Schmalz@klinik.uniregensburg.de

Key words

Human Cells, Dental Materials

\section{References}

1. Schmalz, G; Arenholt-Bindlev, D - editors. Biocompatibility of Dental Materials. Heidelberg: Springer; 2009.

2. International Organization for Standardization: ISO 7405: Dentistry. Preclinical evaluation of the biocompatibility of medical devices used in dentistry: test methods for dental materials. International Organization for Standardization, Geneva 20122013.

3. International Organization for Standardization: ISO 19993 Biological evaluation of medical devices -Part 5: Tests for in vitro cytotoxicity; 2014.

4. Schmalz G, Schuster U, Nuetzel K, Schweikl H. An in vitro pulp chamber with three-dimensional cell cultures. J Endod. 1999 Jan;25(1):24-9.

5. Schmalz G, Schuster U, Koch A, Schweikl H. Cytotoxicity of low $\mathrm{pH}$ dentin-bonding agents in a dentin barrier test in vitro. J Endod. 2002 Mar;28(3):188-92.

6. Schuster U, Schmalz G, Thonemann B, Mendel N, Metzl C. Cytotoxicity testing with three-dimensional cultures of transfected pulp-derived cells. J Endod. $2001 \mathrm{Apr} ; 27(4): 259-65$.

7. Galler K, Hiller KA, Ettl T, Schmalz G. Selective influence of dentin thickness upon cytotoxicity of dentin contacting materials. J Endod. 2005 May;31(5):396-9.

8. Demirci M, Hiller KA, Bosl C, Galler K, Schmalz G, Schweikl H. The induction of oxidative stress, cytotoxicity, and genotoxicity by dental adhesives. Dent Mater. 2008 Mar;24(3):362-71.

9. Galler KM, Schweikl H, Thonemann B, D'Souza RN, Schmalz G. Human pulp-derived cells immortalized with Simian Virus $40 \mathrm{~T}$ antigen. Eur J Oral Sci. 2006 Apr;114(2):138-46.

10. Galler KM, D’Souza RN, Hartgerink JD, Schmalz G. Scaffolds for dental pulp tissue engineering. Adv Dent Res. 2011 Jul;23(3):333-9.

11. Erickson IE, Huang AH, Chung C, Li RT, Burdick JA, Mauck RL. Differential maturation and structure-function relationships in mesenchymal stem cell- and chondrocyte-seeded hydrogels. Tissue Eng Part B Rev. 2008 Jun;14(2):199-215.

12. Ahmed TA, Dare EV, Hincke M. Fibrin: a versatile scaffold for tissue engineering applications. Tissue Eng Part B Rev. 2008 Jun;14(2):199-215.
13. Zhang S. Fabrication of novel biomaterials through molecular self-assembly. Nat Biotechnol. 2003 Oct;21(10):1171-8.

14. Glowacki J, Mizuno S. Collagen scaffolds for tissue engineering. Biopolymers. 2008 May;89(5):338-44.

15. Kim NR, Lee DH, Chung PH, Yang HC. Distinct differentiation properties of human dental pulp cells on collagen, gelatin, and chitosan scaffolds. Oral Surg Oral Med Oral Pathol Oral Radiol Endod. 2009 Nov;108(5):e94-100.

16. Ehrlich HP, Hunt TK: Collagen Organization Critical Role in Wound Contraction. Adv Wound Care (New Rochelle). 2012 Feb;1(1):3-9.

17. Sumita Y, Honda MJ, Ohara T, Tsuchiya S, Sagara H, Kagami H et al. Performance of collagen sponge as a 3-D scaffold for tooth-tissue engineering. Biomaterials. 2006 Jun;27(17):3238-48.

18. Berridge MV, Tan AS, McCoy KD, Wang R. The biochemical and cellular basis of cell proliferation assays that use tetrazolium salts. Biochemica 1996;14-19.

19. da Silva JM, Rodrigues JR, Camargo CH, Fernandes VV Jr, Hiller $\mathrm{KA}$, Schweikl $\mathrm{H}$ et al. Effectiveness and biological compatibility of different generations of dentin adhesives. Clin Oral Investig. 2014 Mar;18(2):607-13.

20. Kim MJ, Kim KN, Lee YK, Kim KM. Cytotoxicity test of dentin bonding agents using millipore filters as dentin substitutes in a dentin barrier test Clin Oral Investig. 2013 Jul;17(6):1489-96.

21. Schmalz G, Schweikl H, Hiller KA. Cytotoxicity of a new composite resin material. J Dent Res 2005;84 Special Issue B:296.

22. Schmidt $C$, Ilie $N$. The effect of aging on the mechanical properties of nanohybrid composites based on new monomer formulations. Clin Oral Investig. 2013 Jan;17(1):251-7.

23. Frauscher KE, Ilie N: Degree of conversion of nano-hybrid resinbased composites with novel and conventional matrix formulation. Clin Oral Investig. 2013 Mar;17(2):635-42.

24. Boaro LC, Goncalves F, Guimaraes TC, Ferracane JL, Pfeifer CS, Braga RR. Sorption, solubility, shrinkage and mechanical properties of “low-shrinkage" commercial resin composites. Dent Mater. 2013 Apr;29(4):398-404. 